\title{
TRICHOME MORPHOLOGY IN TEUCRIUM L. (LABIATAE). A TAXONOMIC REVIEW
}

\author{
by \\ TERESA NAVARRO ${ }^{\prime} \&$ JALAL EL OUALIDI ${ }^{2}$
}

\begin{abstract}
Resumen
NAVARRO. T. \& J. El OUALIDI (2000). Morfología de los tricomas en Teucrium L. (Labiatae). Una revisión taxonómica. Anales Jard. Bot. Madrid 57(2): $277-297$ (en inglés).

La micromorfología de los tricomas de las hojas, cáliz, corola y semillas de 56 especies de Teucrium L. pertenecientes a las 9 secciones del género en el área mediterránea ha sido analizada mediante microscopía electrónica de barrido (MEB). Se describen 25 tipos de tricomas, 12 de ellos, nuevos. Los pelos simples con células de paredes delgadas constituyen el único tipo encontrado en la corola y el más ampliamente distribuido en la cara abaxial de las hojas. Los pelos glandulares subsésiles, con 2-4 células, son exclusivos de las semillas y hojas de las especies saxícolas y paleoendémicas. La presencia de pelos simples, cónicos, con células de paredes gruesas, cortos o elongados y generalmente adpresos, proporciona un carácter adicional para clarificar los límites entre la sección Chamaedrys (Mill.) Schreb. y la sección Polium (Mill.) Schreb. Los pelos ramificados no glandulares solamente aparecen en la sección Polium subsección Polium, con excepción de los pelos ramificados de ramas cónicas y células de paredes gruesas encontrados solo en Teucrium barbarum Jahand. \& Maire (sección Chamaedrys) y $T$. heterophyllum L'Hér. (sección Teucrium). Esta última sección está bien definida por la ausencia de pelos simples cónicos con células de paredes gruesas y pelos glandulares en la corola. La sección Teucriopsis Benth. es de particular interés por la presencia exclusiva de pelos glandulares ramificados y peltados en las semillas. La sección Chamaedrys es un grupo homogéneo que se distingue de las otras secciones por un indumento formado sólo por pelos desarrollados a partir de pelos simples cónicos con células de paredes gruesas. Esta sección tiene en común con las secciones Isotriodon Boiss. y Polium subsección Rotundifolia Cohen ex Valdés Berm. \& Sánchez Crespo la presencia de pelos glandulares en la superficie de las semillas. El tipo de tricomas de los dientes del cáliz, de la cara abaxial de la hoja y de los lóbulos látero-posteriores de la corola pueden ser usados como un carácter taxonómico distintivo a nivel específico y subespecífico. Este estudio apoya la delimitación de secciones de Bentham con las posteriores adiciones de Boissier.
\end{abstract}

Palabras clave: Labiatae, Teucrium, taxonomía, microcaracteres, indumento de la hoja, cáliz, corola y superficie de las semillas.

\begin{abstract}
Navarro, T. \& J. El Oualidi (2000). Trichome morphology in Teucrium L. (Labiatae). A taxonomic review. Anales Jard. Bot. Madrid 57(2): 277-297.

The micromorphology of trichomes of 56 Teucrium $\mathrm{L}$. species belonging to the 9 sections of the genus in the Mediterranean area was surveyed by scanning electron microscopy (SEM) of leaves, calyx, corolla and nutlets. 25 trichome types are described, 12 of them are new. Thin-
\end{abstract}

\footnotetext{
1 Departamento de Biología Vegetal, Facultad de Ciencias, Universidad de Málaga. E-29018 Málaga (Spain). e-mail: tnavarro@uma.es

2 Institut Scientifique, Département de Botanique et d'Ecologie Végétale, Université Mohammed V. BP 703 Rabat (Morocco).e-mail: eloualidi@israbat.ac.ma
} 


\begin{abstract}
walled hairs are the exclusive type found in the corolla and are the most widespread type on the abaxial side of the leaves. Subsessile glandular hairs, 2-4-celled, are found on the nutlet and leaves of the semi-shrubby and paleoendemic species. The presence of short or elongated, generally adpressed simple thick-walled slightly conical hairs provides an additional character to clarify the boundaries between sect. Chamedrys (Mill.) Schreb. and sect. Polium (Mill.) Schreb. Branched non-glandular hairs are confined to sect. Polium subsect. Polium, except for the rare branched hair conical and thick-walled type found in Teucrium barbarum Jahand. \& Maire (sect. Chamaedrys) and T. heterophyllum L'Hér. from sect. Teucrium. This last section is well defined by the absence of simple slightly conical thick-walled hairs and the glandular hairs in the corolla. Sect. Teucriopsis Benth. is of particular interest for the exclusive presence of branched and peltate glandular hairs on the nutlets surface. Sect. Chamedrys is a homogeneous group, distinguished from the other sections by an indumentum formed only by trichomes types evolved from the simple slightly conical thick-walled hairs. This section overlaps, in the presence of glandular sub-sessile hair on the nutlets surface, with sects. Isotriodon Boiss. and sect. Polium subsect. Rotundifolia Cohen ex Valdés Berm. \& Sánchez Crespo. The trichomes type of the calyx teeth, abaxial side of the leaf and latero-posterior corolla lobes can be used as a distinctive taxonomic character at specific and infra-specific level. This study supports Bentham's delimitation of sections with the additions subequently made by Boissier.
\end{abstract}

Key words: Labiatae, Teucrium, taxonomy, microcharacters, leaf, calyx and corolla indumentum, nutlet surface.

\section{INTRODUCTION}

The taxonomic value of the indumentum and its importance in systematic and phylogenetic relationships is well known in Lamiaceae and such related families as Verbenaceae and Scrophulariaceae (ABU Assab \& Cantino, 1987; Cantino, 1990; MetCALFE \& ChalK, 1950).

Trichomes are among the most useful taxonomic characters in Teucrium L. Their absence or presence, their typology on the nutlet surface can be used as taxonomic markers in the infrageneric classification of the genus (MARIN \& al., 1994), while the infrasectional classification of sect. Polium is based almost totally on the typology of the trichomes (Puech, 1984; NAVARRo, 1995).

The dependence on micromorphology for the correct characterization of trichome type, diversity and distribution in plant structures leaves, calyx and corolla and their taxonomic value as an additional marker at specific and subspecific level has been demonstrated in some Italian, Polish, Slovakian and Moroccan species from sect. Chamaedrys, Scorodonia and Polium subsect. Rotundifolia (BINIMALECI \& SeRVETTAZ, 1991; BinI-MALECI \& al., 1992: SERVETTAZ \& al., 1992; SERVETTAZ \& al., 1994; ANTUNES \& SevinAte-PinTo,
1991, GrzybeK, 1967; El OuALIDI \& al., 1997).

However, in spite of their stability as a character (DAVIS \& HEYwOOD, 1963), there are no reports on the infrageneric value of the stability, distribution patterns and diversity of trichomes in leaves, calyx and corolla, particularly in regard to the floral features for pollination such as attraction vectors, nectar guides and closed gullet selective mechanism. Furthermore, the taxonomic value of trichomes in Teucrium is confused because of the varying terminology used in the past and because none of the previous classifications accommodate the full diversity of the Teucrium trichome spectrum.

Teucrium is a large and polymorphic genus mainly in Europe, North Africa and in the temperate parts of Asia. The basic sectional arrangement of the genus (BENTHAM, 1835) is based mainly on the calyx and inflorescence type undertake both very variable characters. The difficulty of classifying some species into sections and the uncertainty over the affinities of some of their sections would led us to a micromorphological study of the leaf, calyx, nutlets and corolla in the hope that it clarify the confusion sectional boundaries and interspecific relationships (ABU-ASAB \& CANTINO, 1993) and demonstrate the taxonomic value of these micro-characters. 
In this study, Teucrium sections are recognized in accordance with BENTHAM's delimitation (1835) with the additions made by BOISSIER (1879).

\section{MATERIAL AND METHODS}

This present study is based on field studies as well as herbarium specimens housed at the following institutions (abbreviations following HoLMGREN \& al., 1990): B, BC, E, G, MA, MGC, MPU, ORT, RAB and TFC. The list of species and their origin is given in the Appendix. Light and SEM microscope were used. For SEM studies, several samples were prepared, minimum three, the flowers and calyces being fixed whole after critical point technique in a Balzers CPD-020, while the nutlets were mounted directly on aluminium stubs and covered with $24 \mathrm{k}$ gold in an ion sputter JFC-1100. After coating, they were observed and photographed by a scanning microscope JEOL JSM-840.

Flowers. We studied the adaxial side of the lower lip, principally the central zone (CZ) located between the basal part of anterior lobe (AL) and the entrance of the corolla tube. The lobes (AL; LL, lateral lobes; LPL, latero-posterior lobes) of the lower lip and the inner side of the corolla tube including the stamen base were analysed and trichome types forming part of the floral features for pollination such as the vector of attractions or nectar guides and closed gullet mechanism were described. The epidermal sculpturing of the corolla lobes were also described. The trichomes of the outer and inner side and margin lobes were described, including the type forming part of the closed tube mechanism in immature calyces. For gynodioecious species the calyx and corolla of male-sterile and cosexuals were observed.

Nutlets. Nutlets were previously observed using a light microscope to ensure that they were of normal size and maturity.

Trichomes. Trichome micromorphology and the structure of leaves, calyx, corolla and nutlets were described and classified. The general classification scheme is based on ROE (1971), but the typological classification of glandular hairs is based on CANTINO (1990), and for most of the categories described, thinwalled and thick-walled groups (HARDIN, 1976) were segregated.

The characters of taxonomic interest in the classification were: presence or absence of the secretory cells, glandular and nonglandular: shape of wall of basal and stalk cells, thin-walled and thick-walled, and presence of the transverse wall cells; number and length of the cells in uniseriate trichomes, unicellular or multicellular; presence or absence of few-armed hairs, stellate hairs, dendritic hairs, vermiform hairs and twisted hairs. In addition, the orientation of the trichomes in relation to the epidermal surface (erect, adpressed), the shape (flexuose, curved, hooked, triangular, conic) and finally the presence/absence of micro-papillae in wall cells were analysed.

\section{RESULTS}

The trichome micromorphology of the leaf, calyx and corolla of the following taxa was analysed in 5 species of the sect. Teucrium; all species comprising the sect. Teucriopsis; 4 previously uninvestigated species of sect. Chamaedrys; 5 unstudied species of sect. Scorodonia; 2 of sect. Stachyobotrys Benth.; 2 of sect. Scordium; 5 of sect Spinularia; 4 of sect. Isotriodon; 26 of sect. Polium. Sect. Pycnobotrys Benth. was not studied. The surfaces of 41 nutlets corresponding to otherwise unstudied species were also studied.

\section{Synopsis of trichomes types in Teucrium}

Figures 1-4 shows the common trichomes types in the studied species.

\section{Glandular trichomes}

These constitute an important taxonomic character of the Lamiaceae and Verbenaceae and form part of the floral specialized features for pollination. For each type, the most significant variation is described. Some of 
these types are present in other genera of Lamiaceae whose citation is included. The thin-walled and thick-walled groups are also represented in the clavate glandular trichomes.

\subsection{Simple glandular trichomes}

A: Clavate glandular trichomes. Reported as long/short-stalked gland or capitate trichomes (BINI MALECI \& SERVETTAZ, 1991). Variations in the size and morphology of clavate glandular trichomes are decided by the number, size and disposition of the stalk cell. The number of cells in the secretory head has not been observed. The presence of micro-papillae is rare.

Al: Short clavate glandular trichomes. Reported in Rosmarinus L. (WERKER \& al., 1985), generally with two, large and thin stalk cells or three stalk cells, with reduced neck and usually without micro-papillae (fig. 1a, b).

A2: Long clavate glandular trichomes with 3(5)-cells. With thick-walled cells (fig. 1c), with long thin-walled 3(4)-cells (fig. 1d) illustrated in Scutellaria L. (ABU AsSAB \& CANTINo, 1987), with short large thin-walled cells (fig. 1e), with large thin-walled basal cell with micro-papillae (fig. 1f), with elongated, transverse thin-walled cells (fig. 1g) illustrated in Nepeta L. (HuSEIN \& al., 1989).

B: Subsessile glandular trichomes. Reported as short-stalked bladder-like glands, sunken glandular dots, glandular scales, glandular capitate sessile trichomes or peltate hairs (Bini-Malecei \& SERvetTAZ, 1991). Following the description and typology of ABU-AsSAB \& CANTINO (1987) and based on the number of cells and the cell-wall configuration, the subsessile glandular trichomes correspond to types 1,2 and 4 . Type 1, named B1 (fig. lh), was the most frequently observed types, while type 2 , named B2 (fig. 1i) and type 4, named B4 (fig. $1 \mathrm{j}, \mathrm{k}$ ) were less common.

\subsection{Branched glandular trichomes}

C: Few 2(5)-armed trichomes with lateral glands (fig. 11). BOKHARI \& HEDGE (1971) noticed their presence in Meriandra Benth.

\section{Non-glandular trichomes}

\subsection{Simple, unbranched trichomes}

D: Prick-less-hairs. These are the unicellular epidermal appendages (fig. 2a).

E: Conical thin-walled unicellular hairs, also called papillate long cells. More or less elongated with or without micro-papillae (fig. 2b).

F: Thin-walled trichomes.

F1: Triangular, large and very thin-walled unicellular hairs, with ridges (fig. 2c).

F2: Large, very thin-walled. 2(5)-celled trichomes with an acute apical cell. With ridges and marked internodes (fig. 2d); rare with the crumpled apical cell (fig. 2e); without micro-papillae (fig. 2f).

F3: Short, thin-walled, 2-3-celled trichomes with micro-papillae; the apical cell is erect triangular, acute (fig. $2 \mathrm{~g}$ ).

F4: Short, thin-walled. 2-celled trichomes densely covered by micro-papillae, with the apical cell elongated (fig. $2 \mathrm{~h}$ ), slightly crumpled or falcate and with a smooth basal cell (fig. 2i).

F5: Elongated and flexuose, thin-walled 3-7(11)-celled trichomes with internode distinct, the apical cell acute with micropapillae, the basal cell smooth, each cell transverse to the preceding one; when the apical is very elongated it looks like the vermiform type (fig. $2 \mathrm{j}$ ); illustrated as tuberculate hairs by MARíN \& al. (1994) and reported in Origanum L., Clinopodium L. and Calamintha Mill. by HUSEIN \& al. (1990) (fig. 2k, 1).

\section{G: Thick-walled trichomes.}

G1: Short and slightly conical, thickwalled, 2-celled or rarely 3-celled trichomes, with a pointed short or elongated apical cell and the basal cell without micro-papillae, erect or sometimes slightly curved, some of them illustrated as flask-shaped by BINIMaleCI \& SeRvetTAZ (1991); BarTHLOTT (1980) (fig. 3a, b).

G2: Elongated, generally adpressed, thickwalled 3(5)-celled trichomes. folded with rounded micro-papillae, hooked (fig. 3c); curved (fig. 3d); with falcate and slight thin 
elongated apical cell (fig. 3e); with the apical cell elongated (fig. $3 \mathrm{f}$ ) reported in T. chamaedrys L. by MANZANARES \& al. (1983) and in T. marum L. by BINI-MALECI \& ServettaZ (1991).
G3: Elongated, thick-walled (3)5-7(8)celled trichomes, erect with rounded epidermal cell and marked internode. Erect, 3-celled (fig. 3g), with elongated stalk cells and slightly flexuose (fig. 3h); in a developing
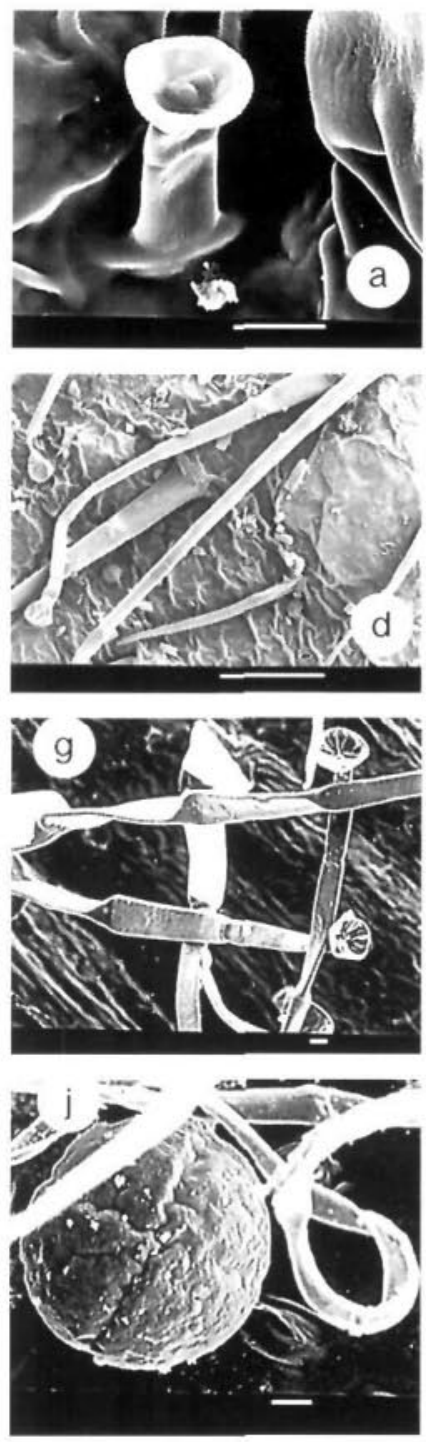
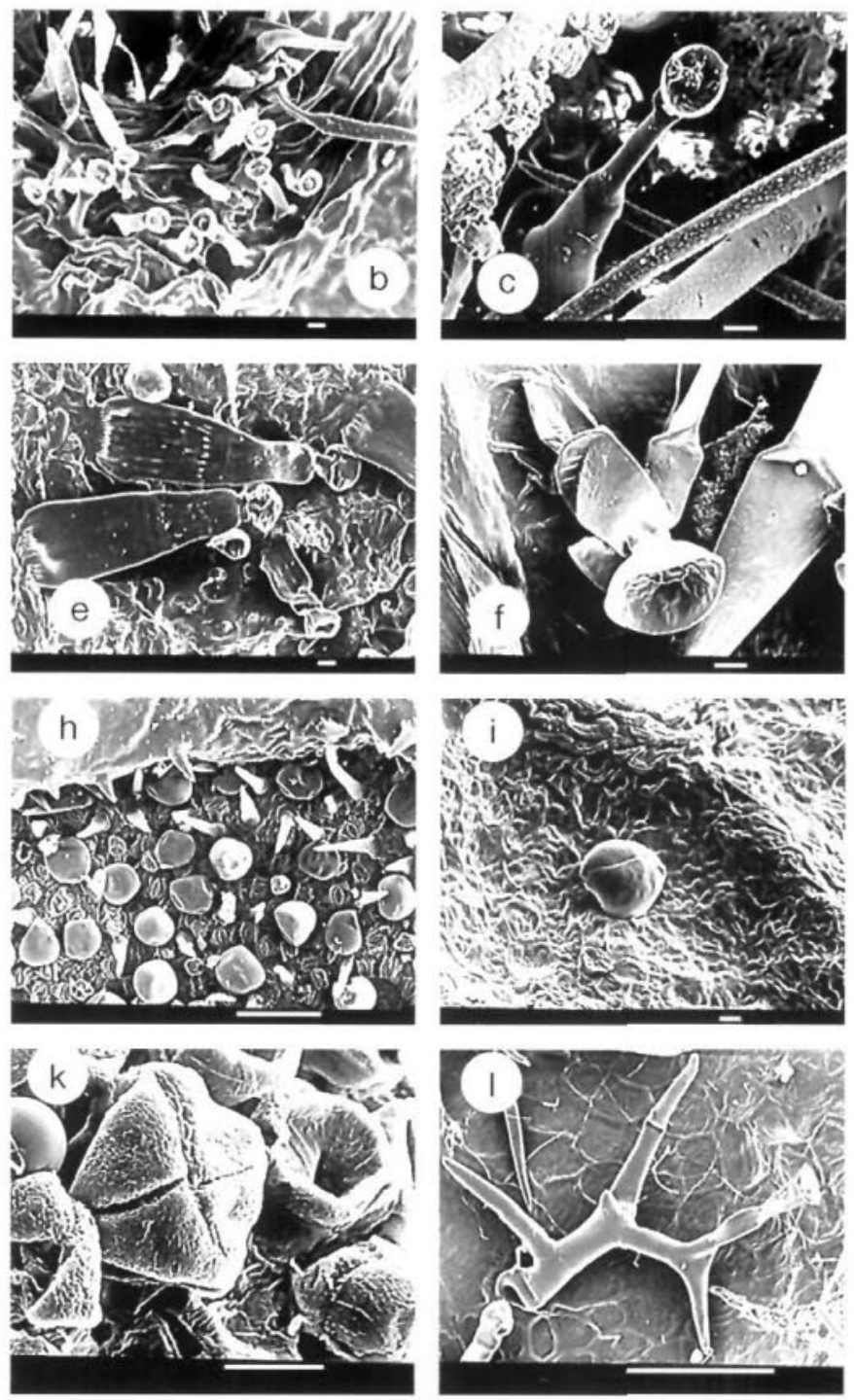

Fig. 1.-SEM glandular trichomes: a, b, Al short clavate: a, Teucrium carolipaui subsp. carolipaui, MGC 6207 ; b, T. fragile, MGC 42191, c-g, A2 long clavate: c, with thick-walled cells, T. persicum, G 8347/73: d, with thin-walled, long cells, T. maghrebinum, BC 811317; e, with thin-walled, large cells, T. odontites, G 8347/21; f, without micropapillae, T. bracteatum, BC 47399; g, with transverse wall cells, T. botrys, BC 811319 . h, i, B subsessile: h, BI onecelled, T. pseudochamaepytis, MGC 48026; i, B2 two-celled, T. rupestre, BC 802723. j, k, B4 four-celled: j, T. eriocephalum, MGC 10900; k, T. tananicum, BC 82723. C branched: I, T. heterophyllum, ORT 2940. [Scale = $100 \mathrm{~mm}(\mathrm{~d}, \mathrm{~h}, \mathrm{l}) ; 10 \mathrm{~mm}(\mathrm{a}-\mathrm{c}, \mathrm{e}-\mathrm{g}, \mathrm{i}, \mathrm{j}, \mathrm{k})$.] 
state (fig. 3i), reported in T. chrysotrichum Lange by MANZANARES \& al. (1983).

$\mathrm{H}$ : Very long inter-twined trichomes, fibrous-like, sometimes coalescent (fig. 3j).
I: Vermiform (lanate) hairs, essentially thick-walled with elongated cells (fig. 3k).

\subsection{Branched trichomes}

It is known that the same hair type can have
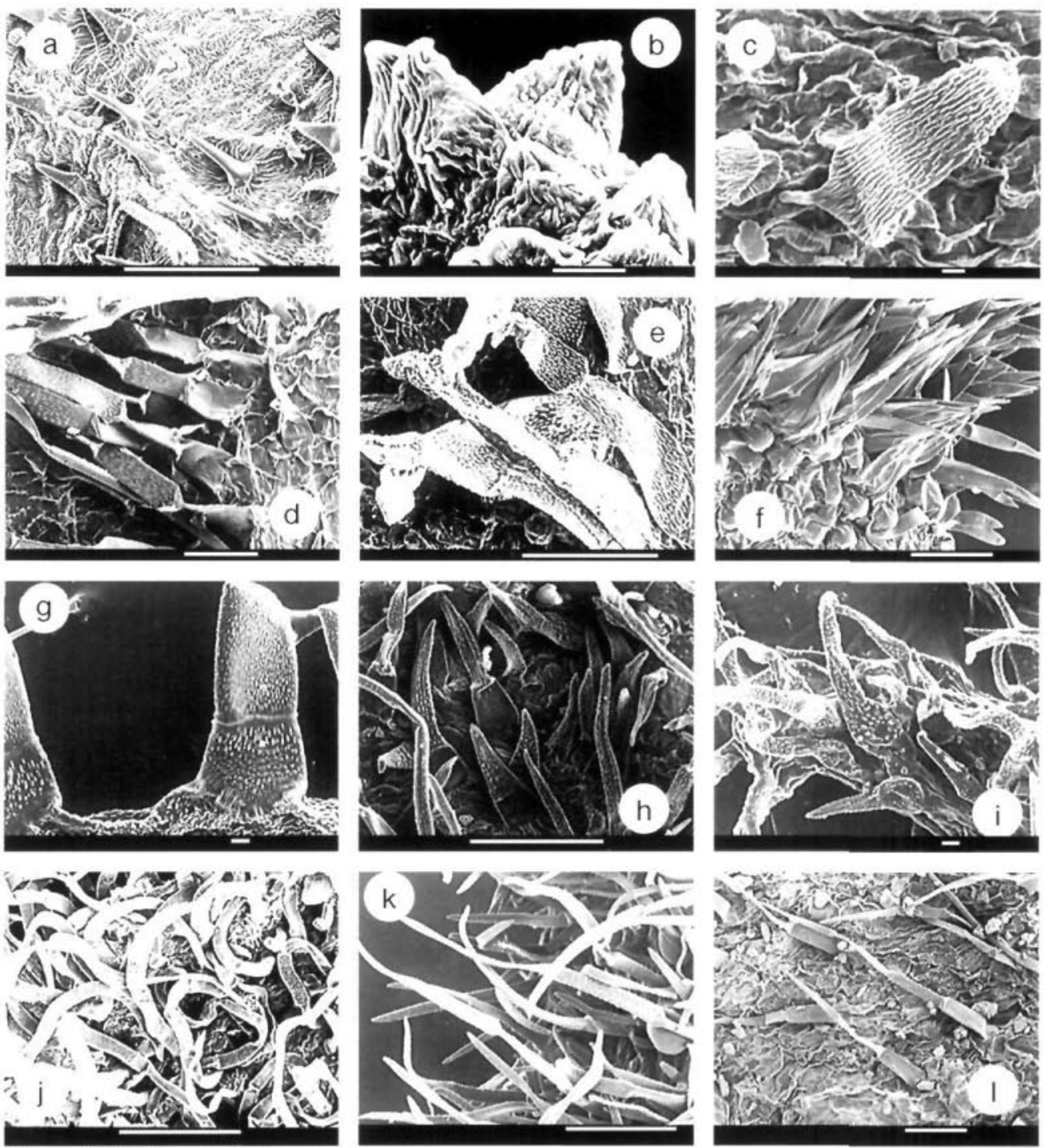

Fig. 2. SEM non-glandular unbranched trichomes: a, D prick-less-hairs, Teucrium afrum subsp. afrum, BC 827294. b, c, E-F1 unicellular: b, conic (long cells), T. maghrebinum, BC 811317; c, larger with micro-papillae, T. rupestre, BC 802723. d-f, F2 multicellular larger, thin-walled: d, T. fragile, MGC 42191; e, with crumpled apical cell, $T$. decipiens, BC 82742; f, without micro-papillae, T. pseudochamaepitys, MGC 48026. g, F3 short with triangular apical cell, T. rotundifolium, MGC 20627. h, i, F4 with elongated apical cell: h, triangular, $T$. collincola, BC 807513; i, crumpled, $T$, betonicum, TFC 13888. j, F5 long, flexuose, T. maghrebinum, BC 811317. k, with elongated apical cell, T. scorodonia subsp. scorodonia, MGC 20986. 1, without micro-papillae, $T$. spinosum, BC 814270 . [Scale $=100 \mathrm{~mm}$ (a, d-f, h, j-l); $10 \mathrm{~mm}$ (b, c, g, i).l 
evolved independently in different lines (MetCAlFe \& ChalK, 1950); for example, the O type corresponds to the branched F4 type and the $\mathbf{J}$ type corresponds to the branched G1 type exemplified in $T$. heterophyllum (ANTUNES \& al., 1997).

\subsubsection{Stellate}

J: Few (2-5) thick armed hairs (fig. 31). Corresponds to branched type of G1.

$\mathrm{K}$ : Two-rayed stellate, multiangular biramous hairs with thick-walled and curved
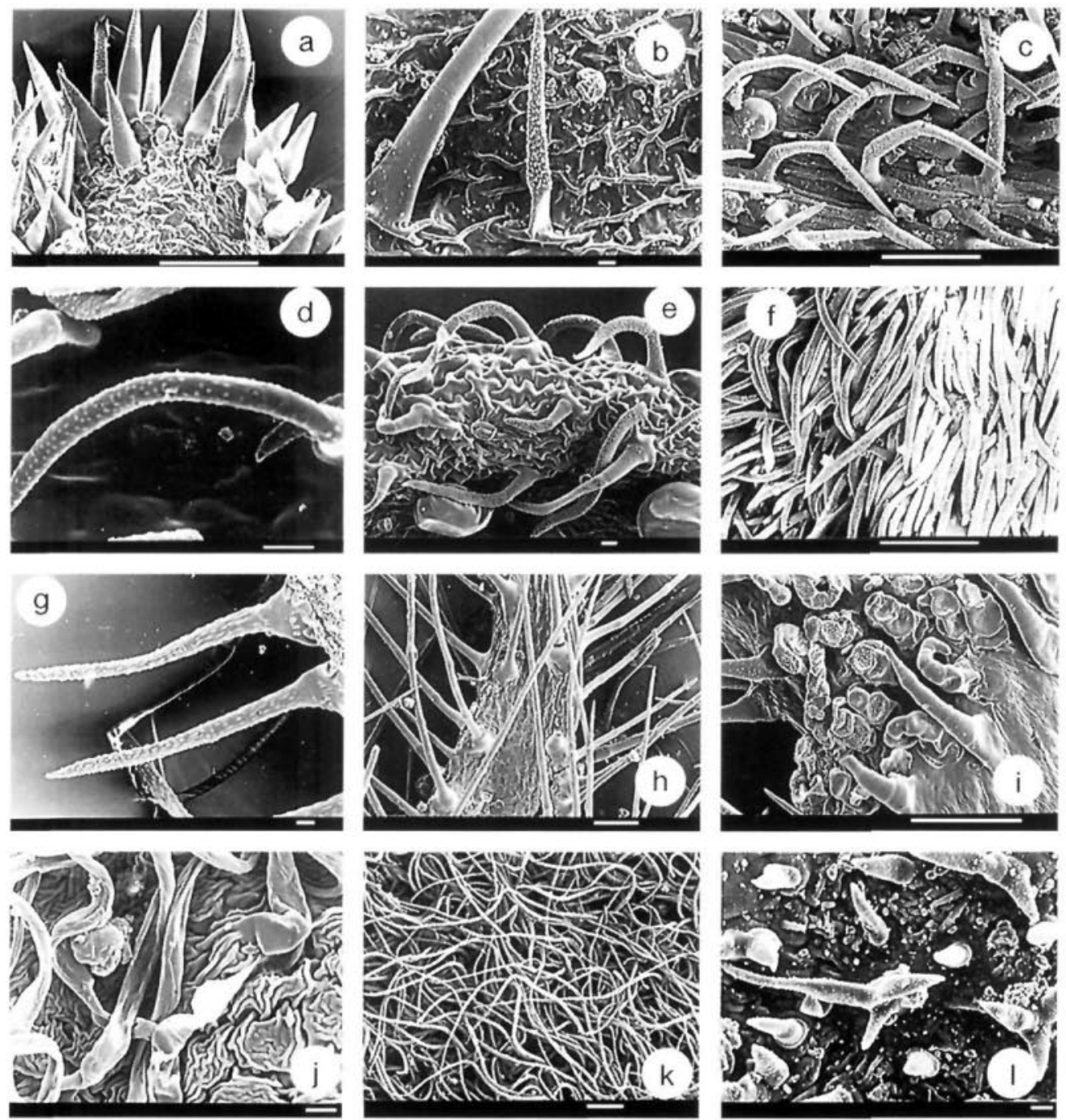

Fig. 3.-SEM non-glandular unbranched and branched trichomes: a, b, GI conic thick-walled: a, Teucrium barbarum. BC 827275; b, T. magrhebinum, BC 827175. c-f, G2: c, hooked, T. chamaedrys subsp. chamaedrys, BC 811281; d, curved, T. thymifolium, MGC 46274; e, with falcate apical cell, T. cincinnatum, E 49029; f, with elongated apical cell, T. rivas-martinezii, MGC 46270. g-i, G3 elongated thick-walled: g, short, T. eriocephalum, MGC 10900; h, long, slightly flexuose, $T$. compactum, B 7399; i, in developing state, T. resupinatum, BC 827175 . j, H inter-twined, T. fruticans, MGC 48025. k, I vermiform, T. yemense. MGC 37049. I, J branched stellate few-armed, T. barbarum, BC 827275. [Scale $=100 \mathrm{~mm}(\mathrm{a}, \mathrm{c}, \mathrm{d}, \mathrm{f}, \mathrm{h}, \mathrm{i}, \mathrm{k}) ; 10 \mathrm{~mm}(\mathrm{~b}, \mathrm{e}, \mathrm{g}, \mathrm{j}, \mathrm{l})$.] 
arms (fig. 4a). Also considered as furcate hairs divided into two branches.

L: Stipitate-stellate hairs, thin-walled (fig. 4b).

\subsubsection{Dendroid or dendritic}

M: Dendritic hairs, with well-developed axis and thick-walled and short acute arms, reported in $T$. carthaginense Lange by ManzanARES \& al. (1983) (fig. 4c).
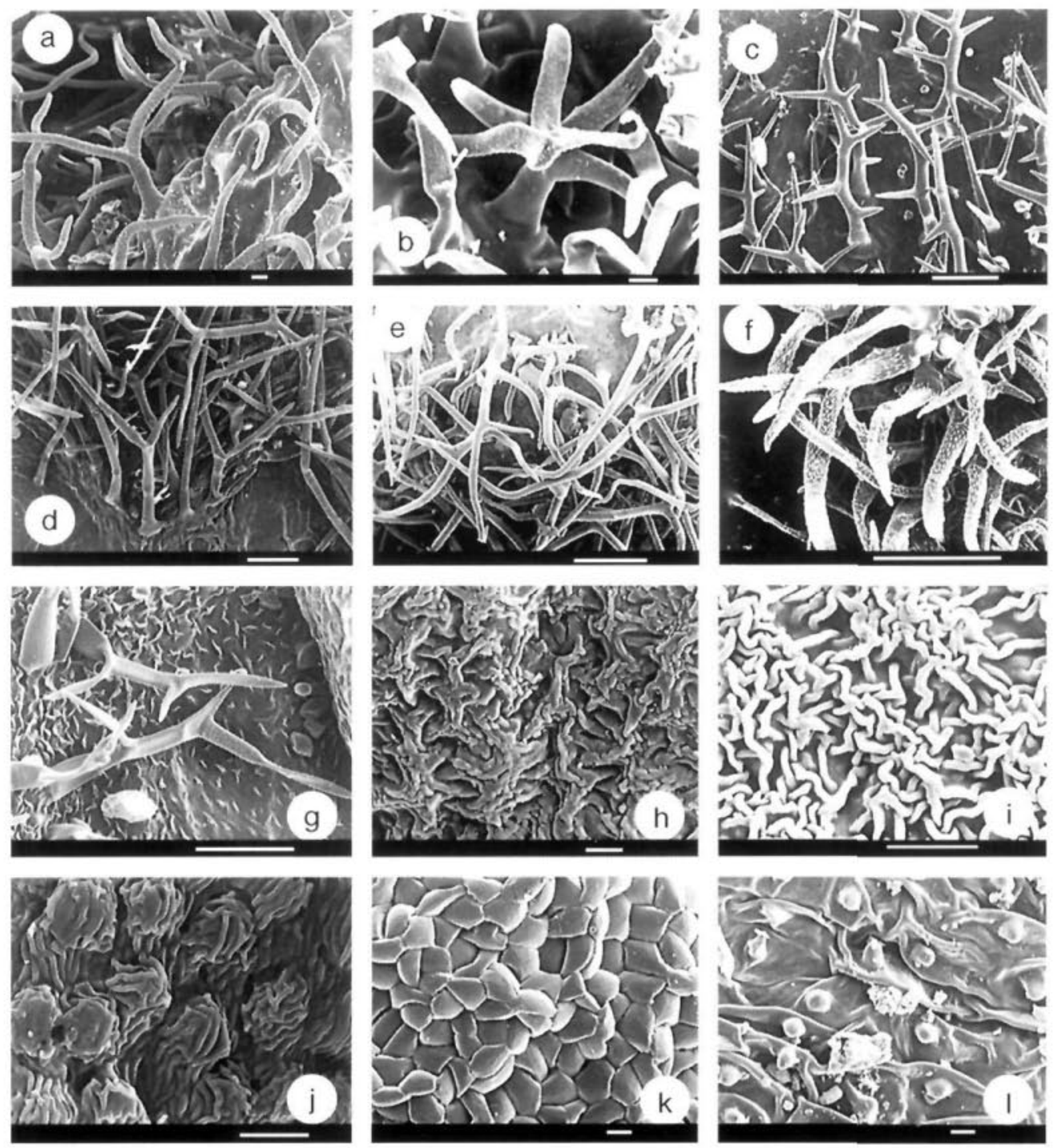

Fig. 4.-SEM non-glandular branched trichomes and epidermal sculpturing: a, $\mathrm{K}$ stellate two-rayed, Teucrium hieronymi, MGC 46232; b, L stipitate-stellate, $T$. capitatum subsp. capitatum, MGC 4374; c, M dendritic, T. homotrichum, MGC 38766; d, N long branched; thick-walled, $T$. dunense, MGC 9030; e, with long axis, T. lusitanicum subsp. lusitanicum, MGC 2057I; f, O with crumpled branches, T. capitatum subsp. capitatum, MGC 4374; g, P with thin-walled branches, $T$. homotrichum, MGC 3876; h-I, ES epidermal sculpturing: h, ESI with thin ridges, $T$. yemense, MGC 37049); i, ES2 with prominent fields, $T$. charidemi, MGC 6191 ; j, ES3 with high prominent ridges, $T$. dunense, MGC 9030; k, ES4 with crossed ridges, $T$. compactum, B 7399; I, ES5 with protusion field, T. abutiloides, TFC 28401. [Scale $=100 \mathrm{~mm}(\mathrm{c}-\mathrm{g}) ; 10 \mathrm{~mm}(\mathrm{a}, \mathrm{b}, \mathrm{h}-\mathrm{l})$.] 
$\mathrm{N}$ : Long branched hairs, with short axis and very long thick-walled arms (fig. 4d) with long axis (fig. 4e).

$\mathrm{O}$ : Branched hairs, with short axis, thinwalled slightly crumpled arms densely covered with micro-papillae, correspond to the branched type of F4 (fig. 4f).

P: Elongated branched hairs, with welldeveloped axis and thin-walled arms, the basal cell without micro-papillae (fig. $4 \mathrm{~g}$ ).

Diagnostic SEM features. The micromorphological characters observed were the following:

PP: Papillae, protusions from outer walls of epidermal cells in the main part of the trichomes (named micro-papillae) (figs. 2c, 4e).

ES: Epidermal sculpturing of the lobes of the corolla. principally the latero-posterior lobes. Drawings of specialized arrangement of epidermal cells: ESI (thin ridges in crossing fields; fig. 4h); ES2 (coalescent thin ridges in prominent fields; fig. 4i); ES3 (high prominent ridges; fig. 4j); ES4 (high prominent ridges crossed; fig. 4k); ES5 (thin ridges in protusion field; fig. 41 ).

\section{Distribution of trichomes}

The morphology and distribution of trichomes in calyx, leaves and pericarp of the nutlets is shown in table 1 , while table 2 shows the same characters from the corolla. Nutlet sculpturing is show in figure 5.

Section Teucrium. The five species examined fall into two groups, one formed by $T$. fruticans $\mathrm{L}$. and $T$. brevifolium Schreb. with $\mathrm{H}$ trichomes in the calyx and leaves and another group formed by $T$. chardonianum Maire \& Wilczek, $T$. pseudochamaepitys L. and $T$. orientale L. subsp. taylori. (Boiss.) Rech. with mainly F4 and F5 trichomes in the calyx and leaves. This is the only section studied with no glandular trichomes in the corolla.

T. orientale subsp. taylori show hairy nutlets with subsessile glandular hairs and reticulate ridges (fig. 5a).

Section Teucriopsis Benth. This section is very heterogeneous. In $T$. betonicum L'Hér. the main trichome type is F5. $T$. heterophyllum show a homogeneous indumentum of $\mathrm{J}$ type branched trichome in the calyx and leaves and, of great interest, C 2(3)-armed trichomes in the inner margin of calyx lobes. Sometimes, the many-branched $\mathrm{J}$ type can be similar in the shape to the dendroid type (M). $T$. abutiloides L'Hér., it is the only species studied which shows a predominance of glandular hairs over all structures this results is according to ANTUNES \& al. (1995).

The nutlets of $T$. heterophyllum (fig. 5b) show reticulate ridges and the distal part is densely covered by 3(4)-celled long branched thin-walled $P$ type trichomes. This is the only species analysed in the genus in which the branched trichomes are present in the nutlets while $T$. betonicum (fig. 5c) is the only species examined with clavate glandular trichomes Al in the nutlet surface.

Section Chamaedrys (Mill.) Schreb. The species studied in sect. Chamaedrys are characterized by the high degree of homogeneity of trichome type, structure and distribution.

The principal trichome type G2, covers all structures. In T. barbarum, the annulus of the inner side of the calyx is formed of branched $P$ type trichome, as occurs in nowhere else in the genus, $T$. barbarum represents an exception in relation to the other species with $\mathrm{J}$ and $\mathrm{G} 1$ on the leaves.

The surface of the nutlets in T. barbarum shows deep fields bordered with thick ridges, more or less completely covered by thinwalled 2(3)-celled F5 trichomes and B2 glandular trichomes, while $T$. fragile Boiss. and $T$. webbianum Boiss. (fig. 5d) display bordered fields, thin ridges and presence of $\mathrm{B} 2$.

Section Scorodonia (Mill.) Schreb. In this section, trichome type varies between species and within the different structures of the same species. The horizontal position of the broad upper lobe of the calyx, leads to an inversion of the indumentum, so that the previous lobes show the same trichomes as the external side of the calyx although in greater abundance.

T. afrum (Emb. \& Maire) Pau \& Font Quer 
subsp. afrum (fig. 5e) possesses nutlets without glandular trichomes and tends to have a smooth surface.

Section Spinularia Boiss. Trichome type and distribution structure vary between species and within structures. Only $T$. resu- pinatum Desf. and $T$. maghrebinum Greuter \& Burdet show similar distribution of the trichomes. And only T. decipiens has F5 in the annulus of the inner side of the calyx like $T$. betonicum. In these species, on the base of mucron or spine of the lobe, the developing
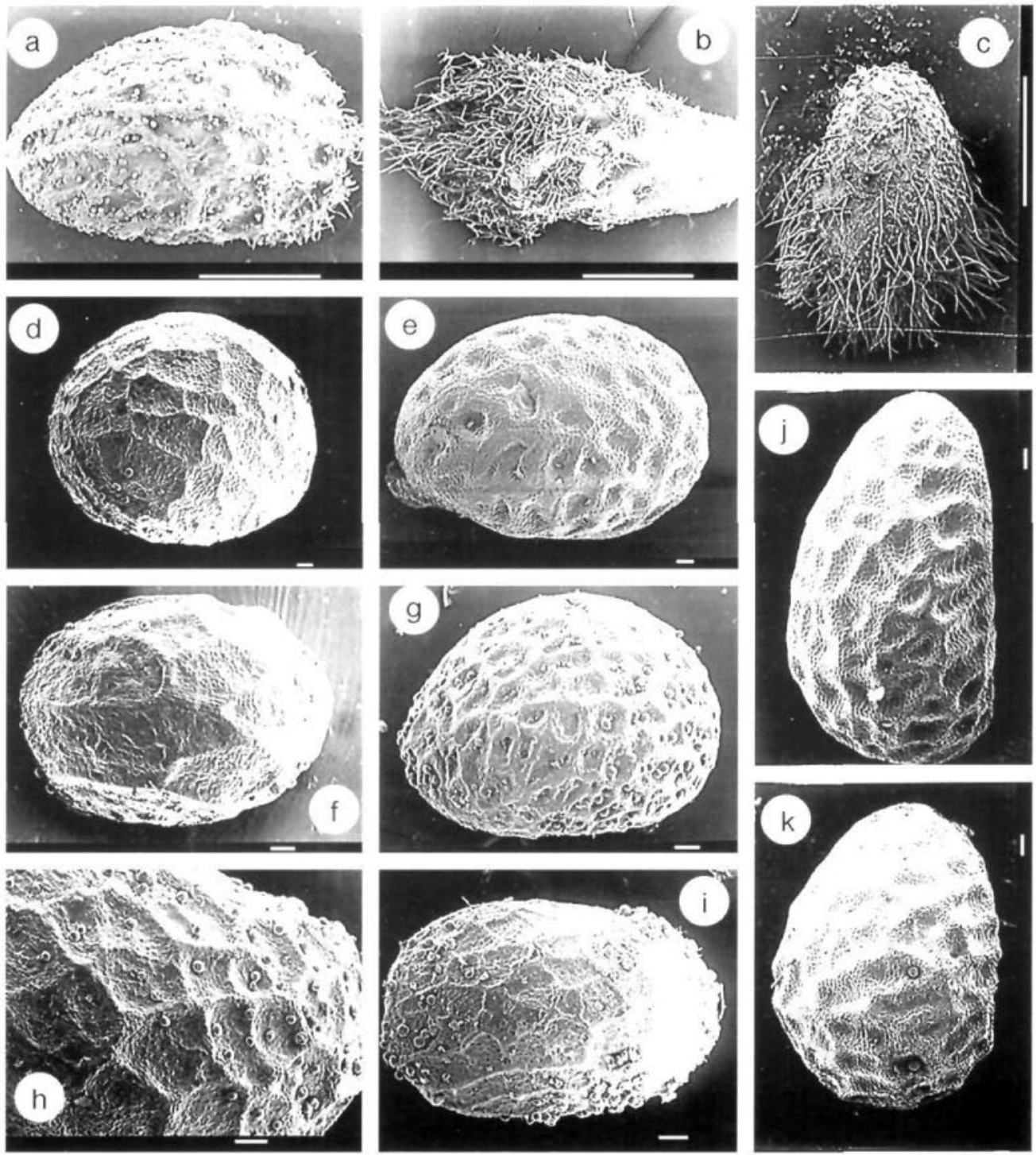

Fig. 5.-SEM nutlets surface: a, Teucrium orientale subsp. taylori, G 8347/33; b, T. heterophyllum, ORT 2940; c, T. betonicum, TFC 13888; d, T. webbianum, MGC 8180; e, T. afrum subsp. afrum, BC 827294; f, T. melissoides, G 8347/18; g, T. collincola, BC 827186; h, T rupestre, BC 802723; i, T. odontites, G 8347/21; j, T. persicum, G 8347/73; k, T. yemense, MGC 37049. [Scale = $1 \mathrm{~mm}(\mathrm{a}-\mathrm{c}) ; 100 \mathrm{~mm}(\mathrm{~d}-\mathrm{k})$.] 
G3 hairs observed may be regarded as playing a role in strengthening the spine (fig. 4h).

Two corolla types are observed. A resupinate corolla in $T$, resupinatum, $T$. decipiens and $T$. maghrebinum with the patches of $F 2$ in the and a corolla without resupination is $T$. botrys $\mathrm{L}$., which shows a reduced patch. In most of the species, the base of the long corolla tube is densely covered F2 hairs, which is an exception in the genus.

Section Scordium (Mill.) Rchb. The two species studied show the same type of nonglandular F5 type trichomes covering the outer side of the calyx and leaves, although T. melissoides Boiss. shows thick-walled G2 type hairs in the lobes of the calyx.

The nutlets of $T$. melissoides (fig. 5f) show subsessile glandular B4 trichomes and tend to have a smooth surface.

Section Stachyobotrys Benth. A great diversity of trichomes was observed in the two species studied. F4, G1 and B1 were found on the outer side of the calyx in both species and F4, B1 and A2 with G1 on the leaves of $T$. collincola Greuter \& Burdet. In this species too, G3 in a developing state is seen on the base of mucro or spine of the lobes, as in sect. Spinularia.

T. collincola shows nutlets with reticulate ridges and subsessile glandular hairs (fig. $5 \mathrm{~g}$ ).

Section Isotriodon Boiss. The main nonglandular trichomes covering all structures are of the G3 type.

T. rupestre Coss. \& Balansa (fig. 5h) and T. odontites Boiss. (fig. 5i) have no reticulated nutlets with the undulating fields and subsessile glandular trichomes distributed on the surface and one or more in the centre of the sunken fields. T. persicum Boiss. (fig. 5j) has the surrounding fields and thick ridges quite deep in these three species. The sculpturing of sect. Isotriodon is similar to that of sect. Strachyobotrys although the ridges in the latter are thick and deep. The presence of $\mathrm{B} 2$ in $T$. rupestre is of interest.

Section Polium (Mill.) Schreb. Trichome type, structure and distribution show high heterogeneity in sect. Polium. In subsect. Polium thick-walled trichomes are the predominant type on the calyx, while stipitate-stellate thin-walled types predominate on leaves. The presence of G3 or F5 is more frequent in hermaphrodite plants than their cosexual counterpart.

T. homotrichum (Font Quer) Rivas Mart. and T. bicoloreum Pau have $M$ hairs. Dendritic trichomes type are present in some species from sect. Polium subsect. Polium from $\mathrm{N}$ Africa as $T$. aureum subsp. gabesianum S. Puech, T. nablii s. Puech (PUECH, 1985, 1990) and T. mideltense (Batt.) Maire, endemic species of the high Moroccan Atlas (EL OUALIDI \& al., 1996). In the gynodioecius species, the bisexual plants show more dense tufts of F5 trichomes in the entrance of the corolla tube than male-sterile ones.

The nutlets have no hairs and their sculpturing shows reticulated fields in contact with the inside part of the calyx.

In the species of subsect. Rotundifolia Cohen ex Valdés Berm. \& Sánchez Crespo except in $T$. pyrenaicum L. subsp. pyrenaicum G3 type 6(11)-celled are the most common hairs on the outer side of the calyx and leaves, generally mixed with $\mathrm{A} 2$ of proportional length as occurs in sect. Isotriodon, except in the case of $T$. yemense Deflers and T. musimonum Humbert, where the leaves and calyx are covered by vermiform trichomes. T. rivas-martinezii Alcaraz \& al., T. cincinnatum Maire, T. thymifolium Schreb. and $T$. sokotranum Vierh. are the only species from this subsection with $\mathrm{G} 2$ type hairs in the calyx and leaves, as occur in the species of sect. Chamaedrys. The leaves of T. thymifolium and $T$. sokotranum also show the same G2 type with apical cells elongated on the adaxial side and thick-walled vermiform trichomes on the abaxial side.

The presence of the subsessile glandular trichomes in the nutlets of $T$. yemense (fig. $5 \mathrm{k}$ ) and the presence of $\mathrm{G} 2$ trichomes in T. thymifolium represents a rare character within sect. Polium.

In the species studied from subsect. Simplicipilosa S. Puech, only T. charidemi Sandwith shows vermiform trichomes. $T$. leucocladum Boiss. and $T$. charidemi has slightly reticulated nutlets and bordered fields 


\begin{tabular}{|c|c|c|c|c|c|c|c|c|}
\hline \multicolumn{9}{|c|}{ 踣 } \\
\hline 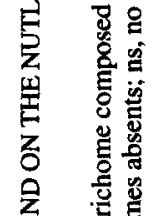 & 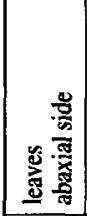 & 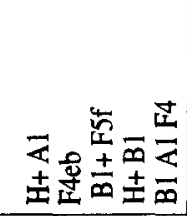 & 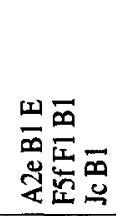 & 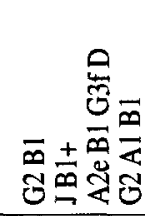 & 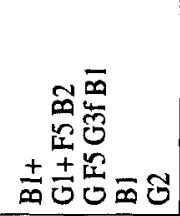 & 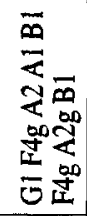 & 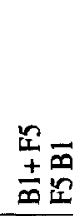 & $\pm \frac{\Phi}{\infty}$ \\
\hline 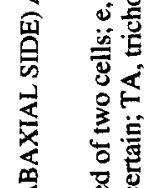 & 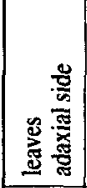 & 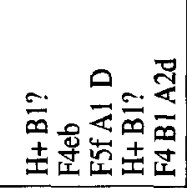 & 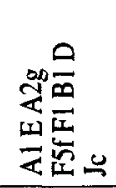 & 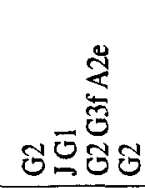 & 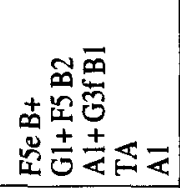 & 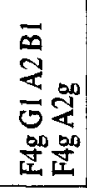 & 芠 & 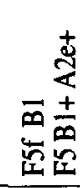 \\
\hline 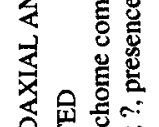 & 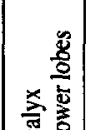 & & & $\overline{\mathbb{D}} \overline{\mathrm{Z}}$ & $<\frac{2}{2}$ & 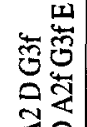 & & حి \\
\hline
\end{tabular}

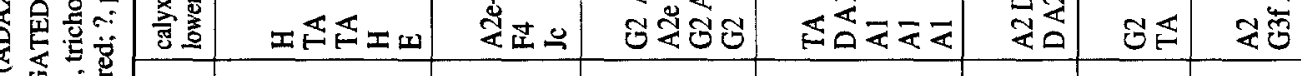

证

西

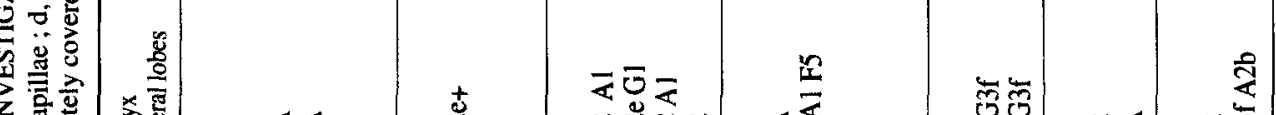
政

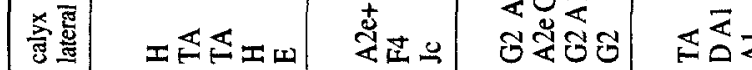

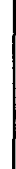

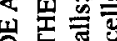

完

(

응

츨

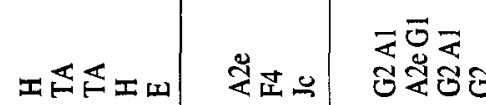

至

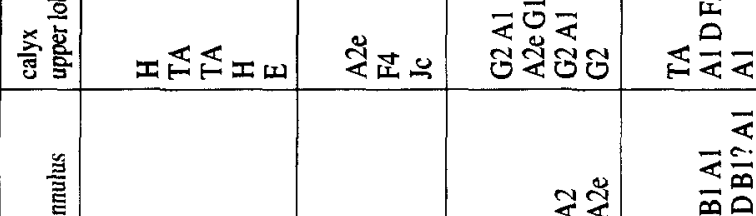

我苛

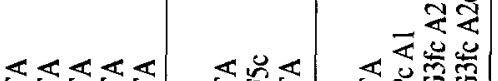

品㟧

促

:

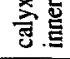

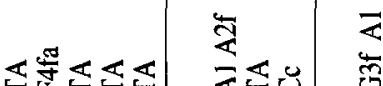

过

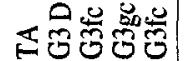
造革

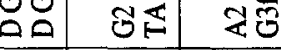

(

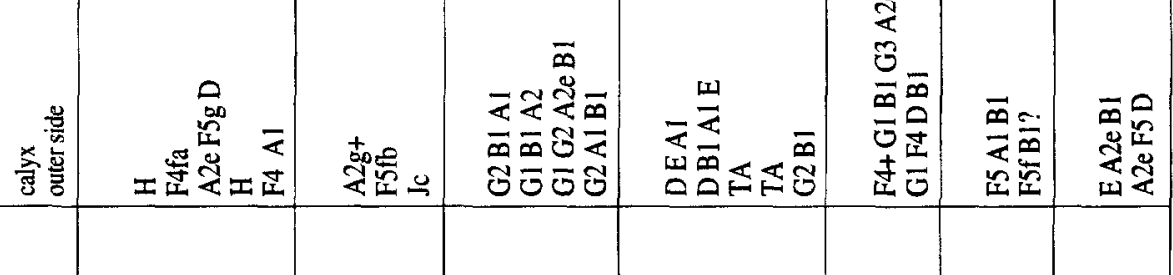




\begin{tabular}{|c|c|c|c|c|c|}
\hline 包是 & 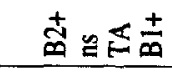 & 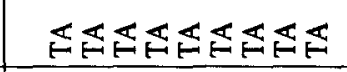 & 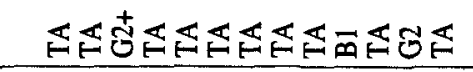 & $\mathbb{E} \notin \mathbb{E}$ & 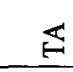 \\
\hline 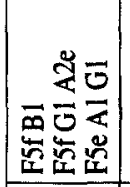 & 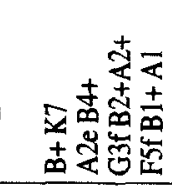 & 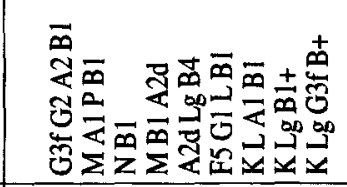 & 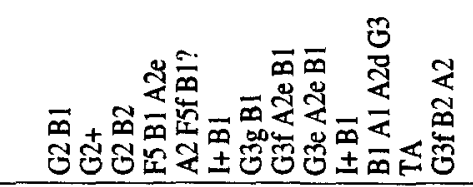 & 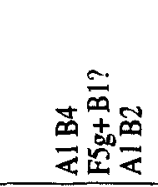 & $\overline{\mathbf{D}}$ \\
\hline 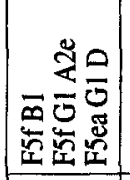 & 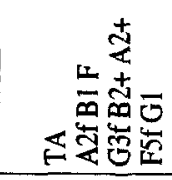 & 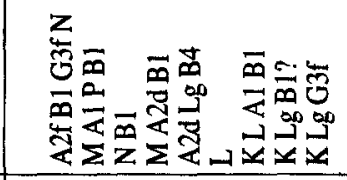 & 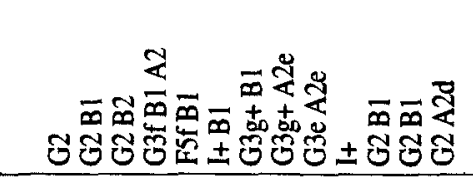 & 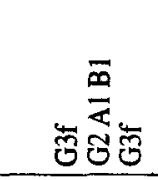 & $\$$ \\
\hline 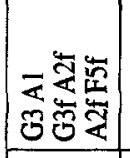 & 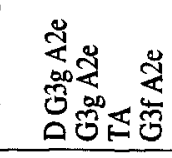 & 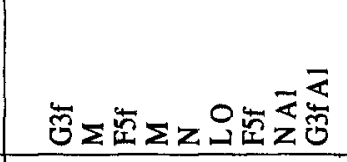 & 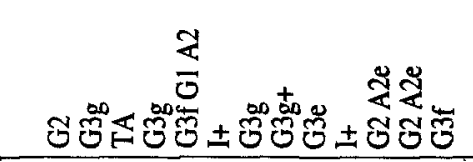 & 芯芯 & ণ্ড \\
\hline 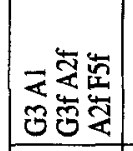 & 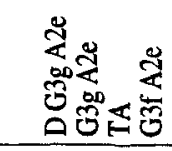 & 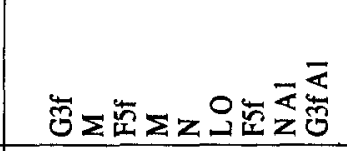 & 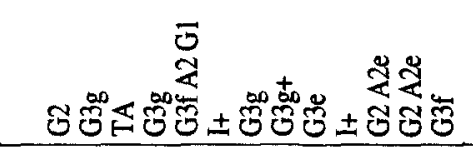 & 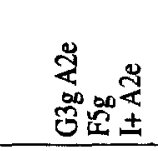 & $\tilde{5}$ \\
\hline 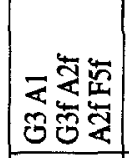 & 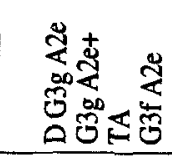 & 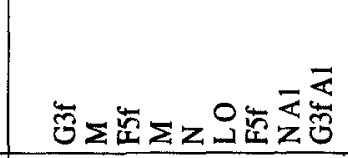 & 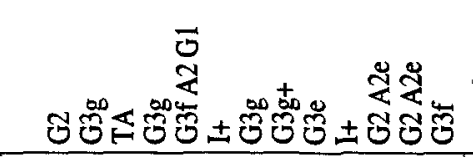 & 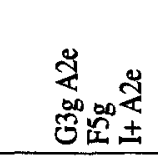 & ণ \\
\hline 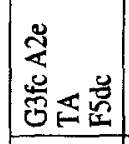 & $\mathbb{E} \mathbb{E} \leqslant \mathbb{E}$ & 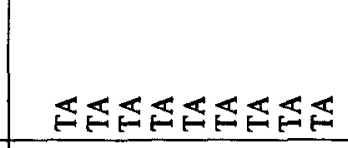 & 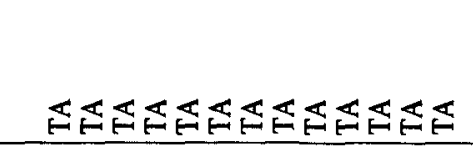 & 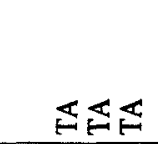 & $\S$ \\
\hline 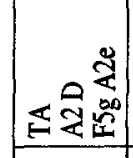 & 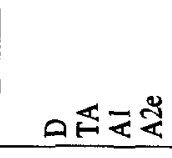 & 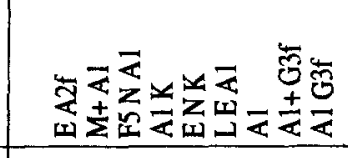 & 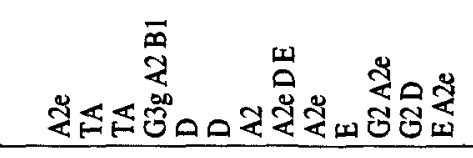 & 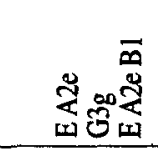 & $\frac{1}{2}$ \\
\hline 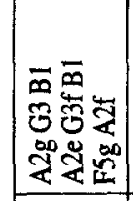 & 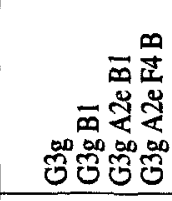 & 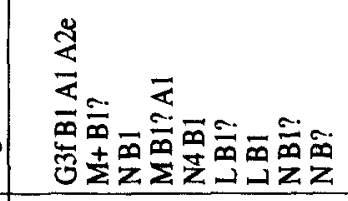 & 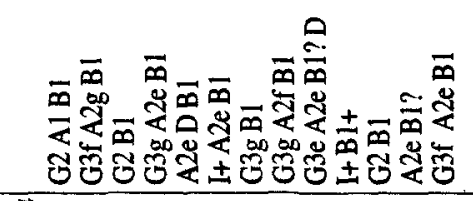 & 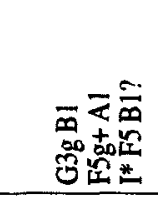 & ণิ \\
\hline 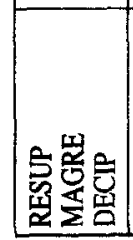 & 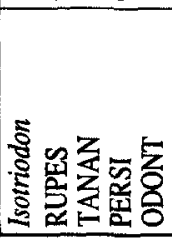 & 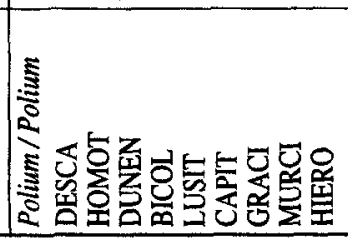 & 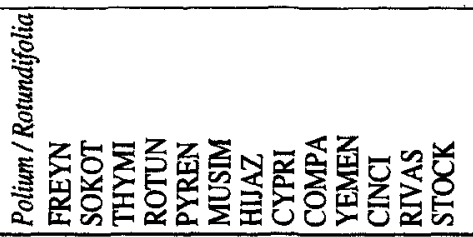 & 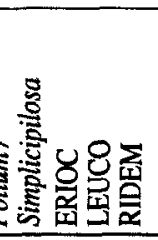 & 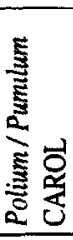 \\
\hline
\end{tabular}




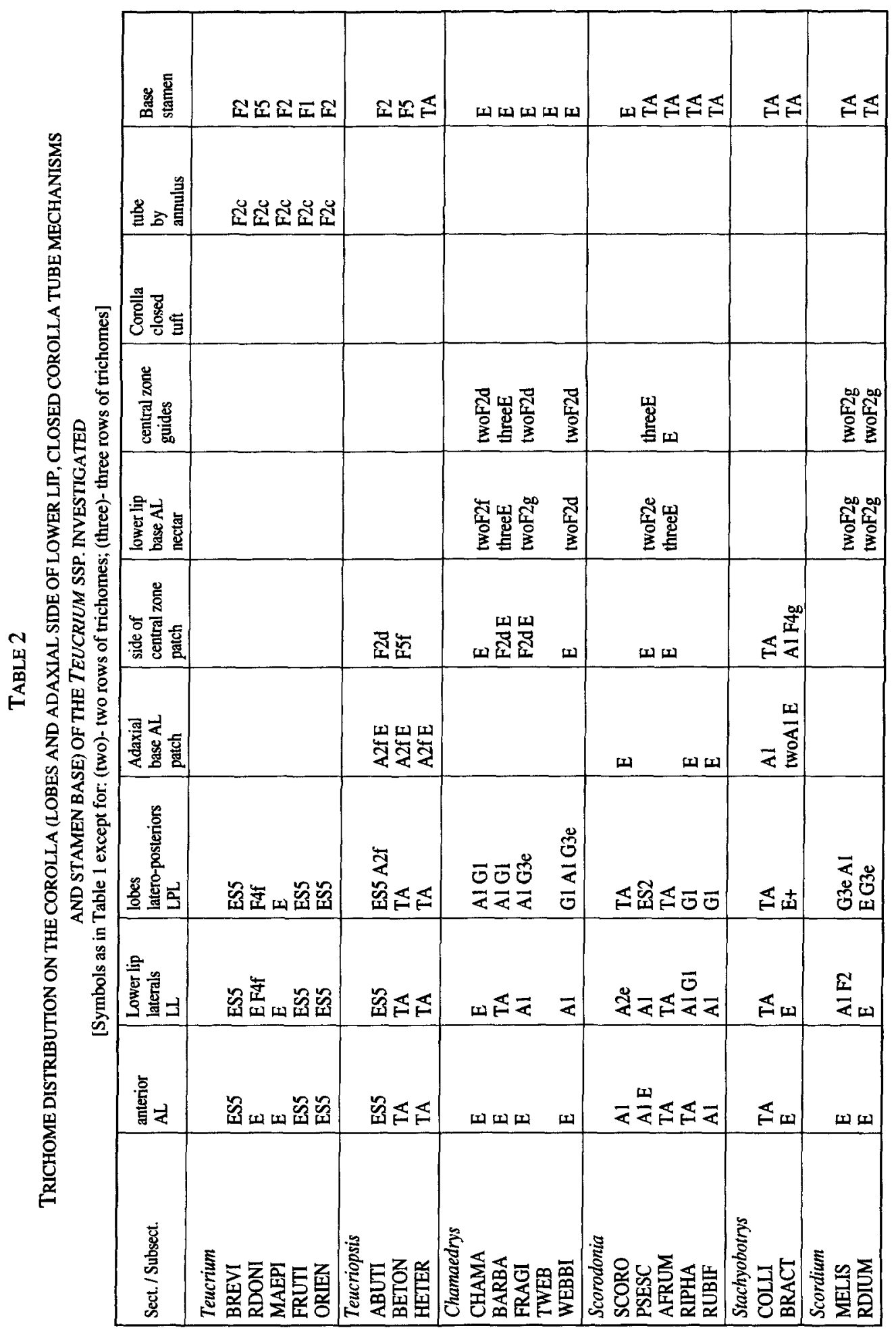




\begin{tabular}{|c|c|c|c|c|c|}
\hline \multirow[t]{2}{*}{ §ほほほほ } & 匡正山四 & 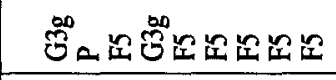 & 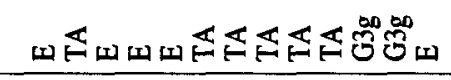 & $\delta^{\infty} \pm \delta^{\infty}$ & w \\
\hline & & 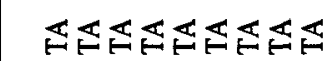 & $\$ \leftleftarrows$ & $\mathbb{E} \mathbb{E}$ & 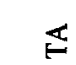 \\
\hline & & 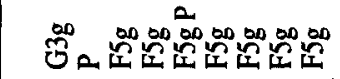 & $\vec{\Sigma} \mathbb{x}$ & $8^{\infty}=80$ & 吉 \\
\hline & 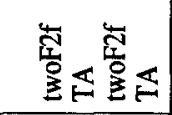 & & 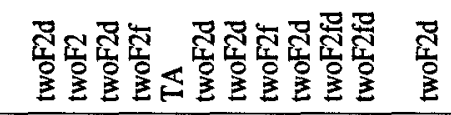 & & \\
\hline & 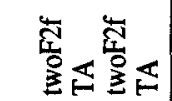 & & 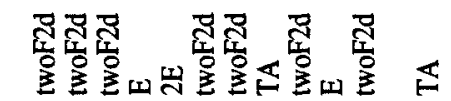 & & \\
\hline 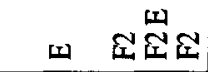 & 艾 & & & $\stackrel{2}{2}$ & $\check{2}$ \\
\hline 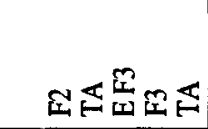 & 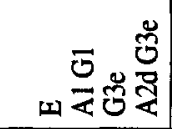 & 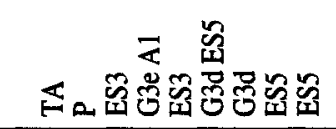 & 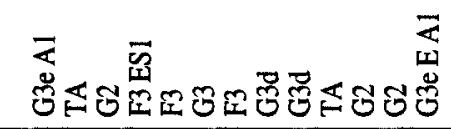 & 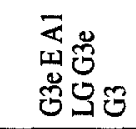 & r \\
\hline 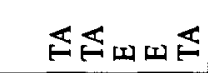 & 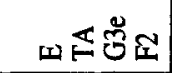 & 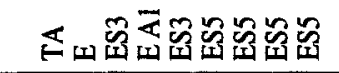 & 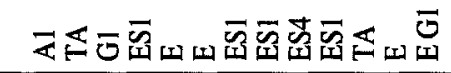 & 画山岗 & 山 \\
\hline 証山に & 凹和山 & 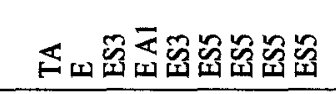 & 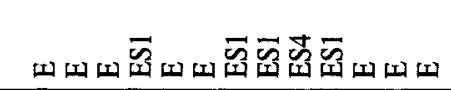 & 岗心瓷 & $\begin{array}{c}\tilde{\tilde{m}} \\
\text { 親 }\end{array}$ \\
\hline 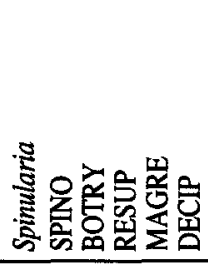 & 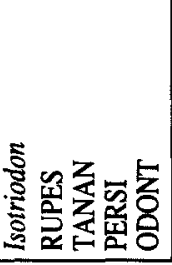 & 吾 & 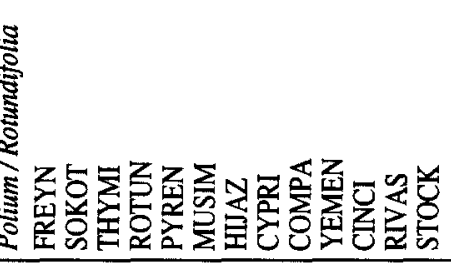 & 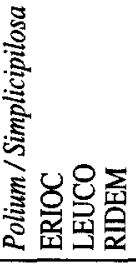 & 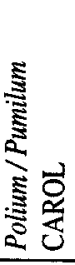 \\
\hline
\end{tabular}


with small and very thin ridges. This sculpturing type is rare in sect. Polium.

In subsect. Pumilum (Lázaro Ibiza) Rivas Mart., T. carolipaui Vicioso ex Pau has mainly G2 trichomes over all vegetative structures as do $T$. rivas-martinezii, $T$. thymifolium and $T$. cincinnatum.

\section{DISCUSSION}

For the standard classification of trichome type in Teucrium, differentiation into thin and thick-walled provides an excellent taxonomic help. Trichome type, distribution and cover vary widely in the different sections of the genus and in the different structures of the same individual plant, as occurs in others Lamiaceae genera (HUSAIN, 1983; DoROSZENKO, 1986; HUSAIN \& al., 1990). Variations exist between the outer and inner side of the calyx and between the adaxial and abaxial surfaces of the leaves, and, within the same individual plant, the cover is always more diverse and dense on the outer side of the calyx and abaxial surface of the leaves.

The micro-papillae are irregulary distributed over the epidermal cell of the trichomes as slight ridges or globose shapes. They are always present on all non-glandular hairs in the non-functional trichomes.

The diversity observed in the calyx structures is correlated with zygomorphy; strictly symmetrical or bilabiate calyces showing lesser indumentum variabilty, while strongly zygomorphic calyces show high variability.

In the adaxial surface of the lower lip and corolla tube, trichomes type and their distribution are extremely homogeneous in all species of the same section and provide a additional character at sectional and subsectional level. A specialised arrangement of the epidermal cells on the inner side of the lateral and latero-posterior lobes of the corolla is rare in the genus, and has only been observed in the species with well-developed lobes from sects. Polium and Scorodonia, as has been reported in Melissa $\mathrm{L}$. genus (FAHN, 1979). It is assumed that they play a role in the visual attraction of the visiting insects.
Glandular and non-glandular trichomes from the same plant structure always belong to only one group. thin or thick-walled, although the clavate glandular trichomes of the floral specializations are always of the thin-walled type.

The distribution of the glandular trichomes is clearly correlated with their role in pollination. A1 type is frequent in the axils and upper part of the inner side of the calyx lobes and in the apical part of the corolla lobes. B1 are totally absent from the adaxial side of the lower lip of the corolla, but appear on the outer side of the calyx and less frequently on the inner side from the insertion of the annulus of hairs to the margin of lobes. B2 and B4 are only observed on the nutlet surface and leaf surface (adaxial and abaxial side, but more frequently on the latter) but never on the calyx structures, and are most frequent in chasmophyte and paleo-endemic species. B4 is the most common type in Scrophulariales and probably represents an ancestral condition in Lamiaceae (CANTINO, 1990). Branched glandular hairs are rare in the genus, only being found in $T$. heterophyllum. Glandular trichomes have a taxonomic value at specific and a subspecific level (MRÁz, 1998) and their presence or absence in the corolla structures can be used as a phylogenetic character.

The presence of branched hairs in vegetative structures has a high systematic value, since they are only universally present in the species of sect. Polium subsect. Polium. They are also present in one rare endemic species of sect. Chamaedrys from Morocco, $T$. barbarum and another isolated endemic species of the Canary Islands, $T$. heterophyllum. The branched hairs in T. barbarum and $T$. heterophyllum are both type J, a type not present in sect. Polium.

In sect. Polium subsect. Polium, the branched hairs are generally mixed with simple hairs on the leaves and less frequently on the outer side of calyx. RYDING (1998), comments that the species related to $T$. polium L. group from the Arabian Peninsula show a clear mixture of the simple and branched hairs, which reflects our findings in $T$. des- 
caisnei C. Presl. The presence or absence of branched hairs in the genus has an important infrageneric phylogenetic significance.

Simple thin-walled trichomes are universally present in the genus, forming part of the floral features for pollination, such as attraction vectors or nectar guides, including a closed gullet mechanism, except in sect. Polium subsect. Polium and subsect. Simplicipilosa. F2 hairs form part of the closed gullet mechanism of sect. Teucrium and the nectar guides in sects. Chamaedrys, Scordium, Isotriodon and sect. Polium subsect. Rotundifolia. F5 and G3 form the trichome tuft of the closed gullet mechanism in sect. Polium subsect. Polium and subsect. Simplicipilosa.

Thin-walled trichomes are the most widespread type on the abaxial side of leaves, occurring commonly in every section except sect. Chamaedrys and only occasionally in sect. Polium subsect. Polium. It is also worth noting that thin-walled trichomes on the adaxial side of the lower lip of the corolla and the abaxial side of the leaves exhibit less intra-sectional variation than other trichome types and are therefore of particular value in assessing intra-generic phylogenetic relationships. F5 type trichomes are present in Calamintha, Clinopodium, Nepeta and are widely distributed through the sections studied except sect. Chamaedrys and less frequent, in sects. Isotriodon and Polium subsect. Polium.

The basic type simple thick-walled hairs (G1 and G2) are the only type present in all the species from sect. Chamaedrys and are completly absent in sect. Teucriopsis and Teucrium. This type provides a good additional taxonomic marker for delimiting the sect. Chamaedrys. The widespread presence of $G$ type trichomes (G1, G2 and G3) in all the sections except in sects. Teucriopsis and Teucrium may have some phylogenetic significance in Teucrium. This basic type also formed the annulus of hairs on the inner side of the calyx in all the species studied except $T$. betonicum and $T$. barbarum.

Nutlets with trichomes represent a primitive character in Teucrium according (MARín \& al., 1994), showing little infra- generic variation. Trichomes are universally present in sects. Teucrium and Teucriopsis and in some European species of sect. Chamaedrys and only in some species from sect. Polium subsect. Rotundifolia from N Africa and SE of Spain. It can therefore reasonably be considered as a character of phylogenetic value at an infrageneric level.

The systematic relationship between sects. Chamaedrys and Teucrium established by MARÍn \& al. (1994) on the basis of the presence of the hairy nutlets in the $T$. marum group, is confirmed by the results obtained in this study of $T$. barbarum, which has a combination of the taxonomic characters of the sect. Teucrium, such as the symmetrical campanulate calyx and $T$. creticum $L$. inflorescence type (NAVARRO \& EL OUALIDI, 1997). In accordance with the results of MARÍn \& al. (1994), T. barbarum of sect. Chamaedrys belongs to the group of species of $T$. marum with trichomes on the nutlets, while $T$. fragile and $T$. webbianum belong to the $T$. flavum L. group. The presence of glandular trichomes in the Mediterranean chasmophytic of sect. Isotriodon, T. rupestre and $T$. odontites, and the presence of glandular trichomes in $T$. yemense and nonglandular trichomes in $T$. thymifolium of sect. Polium subsect. Rotundifolia, established, in accordance with MARín \& al. (1994), a relationship between these sections and sect. Chamaedrys.

BENTHAM (1835) considered that sects. Teucrium, Teucriopsis and Pycnobotrys are the most distinct of the genus. MARÍN \& al. (1994) and HARBONNE \& al. (1986) suggest that sect. Teucrium is totally separate from the other sections of the genus. Our investigation of micro-morphological characters makes us agree with these authors and also reveals the distinctness of the sect. Polium subsect. Polium, sect. Chamaedrys and sect. Teucriopsis from the other sections.

Sect. Polium is the most heterogeneus section as regards trichome type and distribution. Branched trichomes are the only non-glandular trichomes present in the subsect. Polium. Despite this, the morphological diversity is high and acts as 
an excellent taxonomic marker at different taxonomic levels. KäSTNER (1989) combined the sect. Polium under the sect. Chamaedrys, but our results agree with Bentham's delimitations of the sections.

Sect. Teucriopsis is a polymorphic section. Bentham (1835) included two species, T. hetrophyllum, described under the genus Polyodendron Noë and T. betonicum. KÄSTNER (1989), added T. abutiloides, a species considered by Bentham under sect. Pycnobotrys. The affinity between $T$. betonicum and the species of sect. Scorodonia has been mentioned by several authors (BENTHAM, 1848; LINK, 1829). Our results reflect the affinity between $T$. abutiloides and the species of sect. Scorodonia studied, based on the similar distribution patterns of the glandular trichomes and similar patterns in the nutlets sculpturing.

New infrageneric relationships are demonstrated between sect. Chamaedrys and sect. Polium subsect. Rotundifolia, based on the presence of the same type $G 2$ trichome in $T$. freynii, $T$. thymifolium, $T$. cincinnatum and $T$. rivas-martinezii. The taxonomic relationship between the $T$. sokotranum and $T$. buxifolium Schreb. groups from the Iberian Peninsula and between T. hijazicum Hedge \& King and $T$. cyprium Boiss. subsp. cyprium mentioned by KING (1988) are confirmed by our study of trichome micro-morphology, while a new taxonomic affinity is observed between $T$. yemense and $T$. compactum $\mathrm{Clem}$. ex Lag., on the basis of trichome micromorphology and others morphological characters: inflated calyx, elongated spikelike inflorescence and growth habits.

The varied combination of taxonomic characters in sect. Polium, according to NAVARRo (1995), and the observation of trichome micro-morphology strongly suggest taxonomic affinities between $T$. cyprium subsp. cyprium, T. hijazicum, T. stocksianum Boiss. subsp. stocksianum, T. yemense and T. sokotranum with the eastern Mediterranean species of the sect. Polium subsect. Rotundifolia. In the case of T. leucocladum, a species similar to those of the Mediterranean region (KING, 1988) there are close affinities to the Iberian species from sect. Polium subsect. Simplicipilosa.

A study of trichome micro-morphology permits a better understanding of the relationships between the sections investigated. In most cases, character combinations could easily be used as a means of taxonomic identification at different infra-generic levels. The classification of trichome micromorphology adopted here considerably enhances the value of this character within the genus and makes it possible to establish systematic relationships with others genera of Lamiaceae or related families. Variation in the distribution of trichome type in the different sections are of phylogenetic use. This study also supports Bentham's system with the additions made by BoISSIER (1879).

\section{ACKNOWLEDGMENTS}

We would like to express our special thanks to I. Hedge (Royal Botanic Garden, Edinburgh, UK) for his constructive remarks on the manuscript and the loan of specimen from $\mathrm{E}$. We acknowledge P. Cantino (Ohio University, USA) for his comments. Thanks are due to A. Charpin (Conservatoire et Jardin Botanique de la Ville de Genève) for the loan of specimens from $G$. The help provided by J.M. Montserrat (Instituto Botánico de Barcelona, Spain) in the study of BC specimens is gratefully appreciated. Thanks also to Mr. Gayo and Mr. Canca for their technical assistance in SEM and the Directors of the following herbaria: $\mathrm{B}, \mathrm{MA}, \mathrm{MPU}, \mathrm{ORT}, \mathrm{RAB}$ and TFC.

\section{REFERENCES}

ABU-Assab, M.S. \& P.D. CANTINo (1987). Phylogenetic implications of leaf anatomy in subtribe Melittidinae (Labiatae) and related taxa. J. Arnold Arbor. 68: 1-34.

ABu-Assab, M.S. \& P.D. Cantino (1993). Phylogenetic implications of pollen morphology in tribe Ajugeae (Labiatae). Syst. Bot. 18(1): 100-122.

Antunes, T. \& I. Sevinate-Pinto (1991). Glandular trichomes of Teucrium scorodonia L. Morphology and histochemistry. Flora 185: 65-70.

antunes, T., I. Sevinate-Pinto. J.G. Barroso, A.C. Figueiredo, L.G. Pedro, S. Fontinha \& J.J. SCHEFFER (1995). Morphology and histochemistry of trichomes of Teucrium abutiloides L'Hér. 
(Lamiaceae) an endemic species of Madeira. Bol. Mus. Mun. Funchal, Supl. 4: 21-27.

Antunes, T., I. Sevinate-Pinto, A.C. Figueiredo, J.G. BARROSO, L.G. PEDRO, S. FonTINHA \& J.J. SCHEFFER (1997). Morphology and distribution of trichomes in two endemic Teucrium species of Macaronesia. Acta Bot. Gallica 144(3): 363-369.

BARTHLOTT, W. (1980). Morphogenese und Mikromorphologie komplexer Cuticular-Faltungsmuster an Blüten-Trichomen von Antirrhinum L. (Scrophulariaceae). Ber. Deutsch. Bot. Ges. 93: 379-390.

Bentham, G. (1835). Labiatarum genera et species. Teucrium: 660-690. London.

Bentham, G. (1848), Labiatae. In: A.P. de Candolle, Prodomus systematis naturalis regni vegetabilis: 12 . Paris.

Bini-Maleci, L., A. Pinetti \& O. Servettaz (1992). Micro-morphological and phytochemical researches on Teucrium massiliense L. In: R.M. Harley \& T. Reynolds (eds.), Advances in Labiate science: 349 355. Royal Botanic Gardens, Kew.

Bini-MALECI, L. \& O. SERVETTAZ (1991). Morphology and distribution of trichomes in Italian species of Teucrium sect. Chamaedrys (Labiatae). A taxonomical evaluation. Plant Syst. Evol. 174: 83-91.

BoIsSIER, P.E. (1879). Labiatae. In: Flora Orientalis 4: 805-822. Genevae \& Basileae.

BoKHARI, M.H. \& I.C. HEDGE (1971). Observations on the tribe Meriandreae of the Labiatae. Notes Roy, Bot. Gard. Edinburgh 31: 53-67.

CANTINO, P.D. (1990). The phylogenetic significance of stomata and trichomes in the Labiatae and Verbenaceae. J. Arnold Arbor.: 71: 323-370.

Davis, P.H. \& V.H. HeYwood (1963). Principles of Angiosperm Taxonomy. Edinburgh \& London.

DOROSZENKO, A. (1986). Taxonomic studies on the Satureja complex (Labiatae). $\mathrm{Ph}$. D. dissertation, Edinburgh University.

El Oualidi, J., J. Mathez \& S. Puech (1997). Biosystématique et variation géographique: le complexe Teucrium houtii Emb. \& Maire (Labiatae) au Maroc. Candollea 52(1): 59-86.

El Oualidi, J., J.P. Rascol, A. Martin \& S. Puech (1996). Le Poliumoside, marqueur chimique de la section Polium du genre Teucrium (Labiatae): l'exception du T. mideltense, espèce endémique du Maroc. Bioch. Syst. Ecol. 24(3): 261-272.

FaHN, A. (1979). Secretory tissues in plants; 159 pp. Academic Press, London.

GrzYBEK, J. (1967). Morphological and anatomical comparison of species of the genus Teucrium $\mathrm{L}$. indigenous in Poland. Acta Biol. Cracov., Ser. Bot., 10: 39-54.

Harbone, J.B., F.A. TOMÁs-Barberán, C.A. Williams \& M.L. GIL (1986). A chemotaxonomic study of flavonoids from European Teucrium species. Phytochemistry 25: 2811-2816.

HaRDin, J.W. (1976). Terminology and classification of Quercus trichomes. J. Elisha Mitchell Sci. Soc. 92: 151-161.

Holmgren, P.K., N.H. Holmgren \& L.C. BarnetT (1990). Index Herbariorum, Part I: The Herbaria of the world, 8th ed. New York Botanical Garden.
Husain, S.Z. (1983). Chemotaxosystematic studies of Origanum and related genera. Unpublished Ph. D. thesis of the University of Reading.

Husain, S.Z., D.P. Marín, N. Dikuic \& B. Petkovic (1989). Micromorphological and phytochemical studies in two endemic Nepeta (Lamiaceae) species in Yugoslavia. Pakistan J. Bot. 21(2): 210-217.

Husain, S.Z., D.P. Marín, C. Sillc, M. QAiser \& B. PETKOVIC (1990). A micro-morphological study of some representative genera in the tribe Saturejeae (Lamiaceae). Bot. J. Linn. Soc. 103:59-80.

KäSTNER, A. (1989). Übersicht zur systematischen Gliederung der Gattung Teucrium L. Biocosme Mésogéen 6: 63-78.

KING, R.A. (1988). Studies in the Flora of Arabia XIX: Teucrium in the Arabian Peninsula and Socotra. Notes Roy. Bot. Gard. Edinburgh 45: 21-42.

Link, H.F. (1829). Handbuch zur Erkennung der nutzbarsten und am häufigsten vorkommenden Gewächse. Berlin.

Manzanares, P., G. Gómez Campo \& M.E. Tortosa (1983). Estudios sobre el indumento de las especies ibéricas y baleáricas del género Teucrium $\mathrm{L}$. (Lamiaceae). Anales Jard. Bot. Madrid 40: 63-77.

Marín, D.P., B. Petkovic \& S. Duletic (1994). Nutlet sculpturing of selected Teucrium species (Lamiaceae): a character of taxonomic significance. Plant Syst. Evol. 192: 199-214.

Metcalfe, C.R. \& L. Chalk (1950). Anatomy of the diconyledons, 2th ed, I: 201-204. London.

MRÁZ, P. (1998). The structure and development of the glandular trichomes of Teucrium montanum (Lamiaceae). Biol. Bratislava 53/1: 65-72.

NaVARRo, T. (1995). Revisión del género Teucrium L. seccion Polium (Mill.) Schreb. (Lamiaceae) en la Península lbérica y Baleares. Acta Bot. Malacitana 20: $173-265$.

Navarro, T. \& J. el Oualidi (1997). Synopsis of the genus Teucrium L. (Lamiaceae) in Morocco. Acta Bot. Malacitana 22: 187-205.

NAVARRO, T., \& J.L. RosÚa (1988). Nuevas aportaciones al conocimiento de la subsección Simplicipilosa Puech serie Simplicipilosa Navarro \& Rosúa nom. nov. (secc. Polium) género Teucrium (Lamiaceae) en la Península Ibérica. Candollea 43: 173-187.

Puech, S. (1984). Les Teucrium (Labiées) de la sect. Polium du bassin méditerranéen occidental (France et péninsule Ibérique). Naturalia Monspel., Sér. Bot.: 1-71.

PUECH, S. (1985). Contribution à l'étude des Teucrium de la section Polium (Labiatae) de Tunisie (suite). Bull. Soc. Bot. Fr. 132, lettres Bot. (1): 41-50.

PUECH, S. (1990). Contribution à l'étude de biosystématique des Teucrium de la section Polium (Labiatae) de Tunisie. III. Bull. Soc. Bot. Fr. 137, lettres Bot. (1): 63-76.

ROE, E.K. (1971). Terminology of hairs in the genus Solanum. Taxon 20(4): 501-508.

RYDING, O. (1998). Teucrium (Lamiaceae) in NE tropical Africa. Notes Roy. Bot. Gard. Edinburgh 55(2): 209220. 
Servettaz, O., L. Bini-Maleci \& A. Pinetti (1992). Micromorphological and phytochemical characters of Teucrium marum and T. subspinosum (Labiatae) from Sardinia and Balearic Islands. Plant Syst. Evol. 179: $129-139$.

Servettaz, O., A. Pinetti, F. Bellesia \& L. BiniMALECI (1994). Micromorphological and phytochemical researches on Teucrium scorodonia and T. siculum from the Italian flora. Bot. Acta 107: 416421.

WERKER, E., U. RAVID \& E. PUTIEVSKY (1985). Structure of glandular hairs and identification of the major components of their secreted material in some species of Labiatae. Israel J. Bot. 34: 31-45.

\section{APPENDIX}

Alphabetical list of the codes and complete names of the Teucrium investigated and their most frequent synonyms. Abbreviated localities and colllection data for voucher specimens are given. Nomenclature follows KING (1988), NAVARRo (1995), NAVARRo \& EL OUALIDI (1997) and RYDING (1997).

ABUTI Teucrium abutiloides L'Hér.: Madeira, Pico Ruivo, TFC 28401.

AFRUM T. afrum (Emb. \& Maire) Pau \& Font Quer subsp. afrum (T. salviastrum subsp. afrum): Morocco, Chefchaouen, BC 827294; Spain, Málaga, MGC 22978.

BARBA T. barbarum Jahand. \& Maire: Morocco, Fès, BC 827275; Khenifra, Maire 314, MPU.

BETON $T$. betonicum L'Hér.: Madeira, San Jorge, TFC 13888; Eiva do Serrado, TFC 28354.

BICOL T. bicoloreum Sennen: Spain, Jaén, MGC 39850.

BOTRY T. botrys L.: Morocco, Tazaut, BC 811319; Spain, Huesca, MGC 37966.

BRACT T. bracteatum Desf.: Morocco, Xauen, BC 47399.

BREVI T. brevifolium Schreb.: Morocco, Fés, SEV 827231; Lybia, Maire \& Weiller 1263, MPU.

CAPIT $T$. capitatum L. subsp. capitatum: Spain, Madrid, MGC 4374.

CAROL T. carolipaui Vicioso ex Pau subsp. carolipaui: Spain, Alicante, MGC 6207.

CHAMA T. chamaedrys L. subsp. chamaedrys: Morocco, Tazaout, BC 827186; Aknoul, BC 827285; Spain, Soria, MGC 2850.
CINCI T. cincinnatum Maire: Morocco, Ouarzazate, Davis 49029, E; Morocco, Jarro, Emberger 43627, RAB.

COLLI T. collincola Greuter \& Burdet (T. collinum): Morocco, Agadir, BC 807513; Safí, BC 807549.

COMPA T. compactum Clem. ex Lag.: Tunisia, Matmata, Vogt 13136 \& Oberprieler 7441(B); Spain, Almería, MGC 39595.

CYPRI T. cyprium Boiss. subsp. cyprium: Cyprus, Röthlisberger, G 8347/5.

DECIP T. decipiens Coss. \& Balansa: Morocco, Zerhoum, BC 82742; Fés, BC 827221.

DESCA $T$. descaisnei C. Presl. ( $T$. polium var. pilosum): Arabia, Jeddah, G 8437/101.

DUNEN $T$. dunense Sennen: Spain, Almería, MGC 9030.

ERIOC T. eriocephalum Willk.: Spain, Málaga, MGC 10900.

FRAGI $T$. fragile Boiss.: Spain, Granada, MGC 42191.

FREYN T. freynii Willk.: Spain, Murcia, MGC 46532-MA 25676.

FRUTI T. fruticans L.: Morocco, Tizi Ousli, BC 811322; Tazzeka, MGC 48025; Spain, Málaga, MGC 45375.

GRACI T. capitatum L. subsp. gracillimum (Rouy) Váldes Berm.: Spain, Alicante, MGC 6197.

HETER T. heterophyllum L'Hér.: Canary Islands, Tenerife, ORT 2940; Gran Canaria, ORT 8586; Hierro, ORT 18801.

HIERO T. hieronymi Sennen: Spain, Almería, MGC 46232.

HIJAZ T. hijazicum Hedge \& King: Saudi Arabia, Jabal Radwa, (E5941)

HOMOT T. homotrichum (Font Quer) Rivas Mart. ( $T$, aureum subsp. latifolium): Spain, Valencia, MGC 38766.

LEUCO T. leucocladum Boiss.: Arabia, Wadi Hebran (G 8347/16.

LUSIT T. lusitanicum Schreb. subsp. lusitanicum: Spain, Málaga, MGC 20571.

MAEPI $T$. pseudochamaepitys L.: Morocco, Tazzeka, MGC 48026; Spain, Málaga, MGC 45375.

MAGRE T. maghrebinum Greuter \& Burdet (T. mauritanicum de Noë): Morocco, Nador, BC 811317; Al Hoceima, BC 827219.

MELIS T. melissoides Boiss.: Iraq, Erbil, G $8347 / 18$. 
MURCI T. murcicum Sennen (T. polium subsp. aguilasense): Spain, Murcia, MGC 46018.

MUSIM T. musimonum Humbert: Morocco, Djbel Ayachi, MGC 39019; Tichnika, Emberger 44808, RAB.

ODONT T. odontites Boiss.: Libano, Raz Chekka, G 8347/21; Karadouranne, G 8347/24.

ORIEN T. orientale L. subsp. taylori (Boiss.) Rech.: Iran, Khorramabad, G 8347/33; Jahram, G 8347/29.

PERSI T. persicum Boiss.: Iran, Jahrom, G 8347/73.

PSESC T. pseudoscorodonia Desf.: Morocco, Al-Hoceima, BC 827277; Ketama, BC 827278.

PYREN T. pyrenaicum L. subsp. pyrenaicum: Spain, Huesca, MGC 37970.

RDIUM T. scordium L. subsp. scordioides (Schreb.) Arcangeli: Morocco, Djbel Zem-Zem, BC 81 1278; Spain, Huelva, MGC 18238.

RDONI T. chardonianum Maire \& Wilczek: Morocco, Agadir, BC 13683.

RESUP T. resupinatum Desf.: Morocco, Taza, BC 827147; Kenitra, BC 827175.

RIDEM T. charidemi Sandwith: Spain, Almería, MGC 6191.

RIPHA T. afrum (Emb. \& Maire) subsp. riphaeum (Font Quer \& Pau) Castrov. \& Bayon ( $T$, oxylepis var. riphaeum): Morocco, Djbel Lerz, BC 811086.
RIVAS T. rivas-martinezii Alcaraz, Garre, Mart. Parras \& Peinado: Spain, Murcia, MGC46270.

ROTUN T. rotundifolium Schreb.: Spain, Granada, MGC 20627.

RUBIF T. afrum (Emb. \& Maire) subsp. rubriflorum (Font Quer \& Pau) Castrov. \& Bayon (T. afrum var. rubriflorum): Morocco, Tazza, BC 827150.

RUPES T. rupestre Coss. \& Balansa: Morocco, Safí, BC 802723.

SCORO T. scorodonia L. subsp. scorodonia: Spain, Huesca, MGC 20986.

SOKOT T. sokotranum Vierh. (T. petiolare): Socotra (E 10407.

SPINO T. spinosum L.: Morocco, Meknes, BC 814270; Al- Hoceima, BC 827251; Spain, Sevilla, MGC 10463.

STOCK T. stocksianum Boiss. subsp. stocksianum: Pakistan, Baluchistan, G $8347 / 102$.

TANAN T. tananicum Maire: Morocco, Agadir, BC 82723.

THYMI T. thymifolium Schreb. (T. buxifolium subsp. thymifolium): Spain, Murcia, MGC 46274-MA 97924.

WEBBI T. webbianum Boiss.: Spain, Almería, MGC 8180.

YEMEN T. yemense Deflers (T. spicastrum): Djibouti, Ali-Sabieh, MGC 37049.

Editado por Ramón Morales Aceptado para publicación: 26-IV-1999 